\title{
The Study of the Use of FDI to Enhance the Product Competitiveness of Integrated Circuits and Micro-electronic Components
}

\author{
Xiangyang Zhang \\ School of International Business, Southwestern University of Finance and Econonics \\ 55 Guang Hua Cun Street, Chengdu 610074, China \\ Tel: 86-159-2891-8907Ｅ-mail: andyletter@163.com
}

Wei Liu

School of International Business, Southwestern University of Finance and Econonics

55 Guang Hua Cun Street, Chengdu 610074, China

Tel: 86-135-4085-6027 E-mail: liuweiswufe@163.com

\begin{abstract}
Integrated Circuit (IC) industry as the cornerstone of economic development of information society with great penetration on traditional industries, as well as playing the leading role in traditional industries, has become the focus of the current international competitiveness. What is more, IC has also become an important indicator which measures the modernization and overall national strength of a country or a region. Therefore, the competitiveness of the products of integrated circuits and the products of micro-electronic components has become more social and economic significance. This paper which is on the basis of a model country (U.S.) for the future development goals and a example country (South Korea) for the comparison of current development explore the competitiveness of the status quo of China's integrated circuits and the products of micro-electronic components, and through the development of the advantages of FDI in South Korea, indicate that how to use FDI in order to enhance the competitiveness of space for development of integrated circuits and micro-electronic components in china.
\end{abstract}

Keywords: FDI, Competitiveness of the products, Integrated circuit

At present, the electronic information industry as the core of integrated circuit has over the traditional industries as the representative of car, oil, iron and steel to become the first major industry, which is powerful engines and solid cornerstone that transforming and pulling traditional industries into the digital age. The data of modern economic shows that each $1 \sim 2$ Yuan output of integrated circuits, lead 10 Yuan industrial output in form of electronic and then promote 100 Yuan of GDP growth. Currently, the 65 percent of the economic growth of GDP of developed countries is related to IC. As the focus in today's world economic competition, the integrated circuit which with their own copyright has become the lifeblood of economic development, social progress, the basis for a bargaining chip in international competition and the protection of national security. In the 1990s, the integrated circuits of the electronics industry (HS1992: 85) for the import and export throughout the world, is only second to the nuclear industry (HS1992: 84), and in the year 2000, it has become the top one in the world both in the import and export.

The competitive power of export products is an economic potentiality manifestation of a country, which reflects the competitiveness of a country in products, business, industry at different levels of international competition, involving many factors in the field of external economic cooperation. China is a large trading nation, but not the powerful. The main reason for this is that our export competitiveness is not high enough. Therefore, doing research on electron industry, especially in electronic core product --- the competitive power of the products of integrated circuit and micro electron module (HS1992:8542), has important practical significance as measure the development of China in the future.

\section{Introduction}

The relations of a country's foreign direct investment to this country's foreign trade whether supplementary or substitutes, is a long-term academic question that has not come to a conclusion, and thus, it has also drawn out many discussions about product competitive power of FDI. After the data analysis of Latin American and East Asian countries, Hein (1992) believed that the countries that carried out the successful export promotion policy attracted a lot of FDI, but the expansion of exports was before the growth of FDI in the succession. Zhang and Felmingham (2001) 
also obtained similar conclusions through the research on the relationship between the use of FDI and the exports in China. The findings of these studies were the expansion of exports had attracted the entry of FDI. However, Bayonmi, Lipworth (1995), Muchielli, Chedor (1999) and so on, held the opposite point of view with the above result according to their research conclusions. They thought that the FDI growth caused a country export scale increase, namely FDI growth before, export scale expansion after. They pointed out that FDI carried on the developing country had some advantages the enterprises of host country did not have, such as the international market experience, more perfect international sales network, more advanced technology and management and so on. Therefore FDI may enhance country export competitive power greatly. Ng and Yeats (2003) also had the similar viewpoint. F. Gerard Adams, Byron Gangnes and Yochanan (2006) through the studies on Chinese competitive power pointed out that there is the relationship between FDI and Chinese export competitive power.

Many Chinese scholars have conducted the related research on FDI and the competitive power. Most of them used macroeconomic data making the regression analysis or the relevant analysis on the FDI and exports value, FDI and imports value, FDI and import and export value, which indicated that FDI had the promoter action and the reciprocity to our country's value of exports, the import value and the import and export value. Zhang Shousen (2005) thought that FDI affected our country competitive power through many kinds of ways. Cai Maosen and so on (2005) believed that there was a significant positive correlation between FDI and the development of export trade of our country, what's more, he also argued that FDI had become the important constitution factor and the growth fountainhead of Chinese trade export competitive power. Wang Suqin (2005) had done some research on export competition power of industrial finished products and she thought that our country export products had certain international competitiveness in the domain of labor-intensive form. Shen yajun (2006) did the study on the impact of FDI on export competitiveness of high-tech products and he indicated that the FDI could promote the export competitiveness of high-tech products. From the above we can see that domestic and foreign scholars not only pay more attention on the research of the relationship between FDI and foreign trade, but also attach great importance to research on the overall structure.

We can also see that most empirical research on products competitiveness still stay in FDI and the changes of the structure of goods, and the research that adopted to measure the competitiveness of products is fewer, which mainly study the effect of FDI on the product. So, in this paper, on the basis of previous studies, I will compare Chinese products Competitiveness index of integrated circuits and micro-electronic components with the United States and South Korea respectively, and analyze the impact of FDI inflows on the products competitiveness both in China and South Korea from the model so as to determine whether the introduce of FDI in China can enhanced competitiveness development space of integrated circuits and microelectronic Component product in the future.

2. The export competitiveness of integrated circuits and micro-electronic components: The empirical analysis and comparison of The United States, China and South Korea

\subsection{The popular indicators assessing the competitiveness of export products}

Internationally, it is very popular to use Revealed comparative advantage index, Trade Competition index, and Market Share index these three important indicators to analyze the competitive power of export products of on country.

Stated simply, the revealed comparative advantage of country $j$ in the trade of product $j$ is measured by the item's share in the country's exports relative to its share in world trade. That is, if Ej is the value of a country's exports of product $j$, and Et is the country's total exports, its revealed comparative advantage index is: $\mathrm{RCA}=(\mathrm{Ej} / \mathrm{Et}) /(\mathrm{Wj} / \mathrm{Wt})$. Where the w subscripts refers to world totals. The index RCA has a relatively simple interpretion. Generally speaking, if it takes a value of less than 1 this implies that the country has a revealed comparative disadvantage in the product. Similarly, if the index exceed 2.5 this implies that the country has a strong revealed comparative advantage in the item. And if the value of RCA is between 1 and 2.5, this implies that the country has a relatively strong revealed comparative advantage.

The formula of Trade competitiveness index $(\mathrm{TC})$ is: $\mathrm{TC}=(\mathrm{Ej}-\mathrm{Ij}) /(\mathrm{Ej}+\mathrm{Ij})$.in this formula, Ej is on behalf of one kind of industry exports of a country and $\mathrm{Ij}$ is the imports. TC changes between 1 and -1 . If TC $>0$, it means that this industry is in a dominant position. Oppositely, if TC $<0$, it implies this industry is at a competitive disadvantage. TC $=1$ and TC $=-1$ means that the industry of a country only imports or exports, which is under an extreme condition.

The formula of International market share (MS) is $\mathrm{MS}=\mathrm{Ej} / \mathrm{Wj}$. And in this, $\mathrm{Ej}$ and $\mathrm{Wj}$ are respectively on behalf of the value of goods export of a country and of the world. In addition, the higher the value of MS is, the stronger the international competitiveness of such goods in the country will be.

2.2 The analysis of the products of integrated circuits and micro-electronic components competitiveness of United States, China, and South Korea (HS1992: 8542) (the data is from trade goods database of the United Nations: http://comtrade.un.org/)

The United States is a technical leading country of the products of integrated circuits and micro-electronic components, and at the same time both of its value of RAC and TC show that it has advantages in products; especially, we can see that it is in an extremely competitive position. And we also find that its value of RCA is bound in a relatively stable 
range, and its market share is quite high, but as the time goes by, its market share is declined continually, which mainly due to Japan's development of technique of integrated circuits and micro-electronic components, as well as the rapid growth of being processing large country of integrated circuits and micro-electronic components of South Korea and Taiwan. However, in this regard, these do not affect the leading position of U.S. being the leader of the global integrated circuit and micro-electronic components market in the aspects of research and development (see table 1).

South Korea show significant comparative advantage with the comparison with the USA. From 2001 to 2003 , the global semiconductor industry is at low ebb, which affected South Korea's integrated circuits and micro-Electronic component products significantly, and the exports of South Korea within this period have eased substantially, making the value of TC to be negative. However, with the warming of the semiconductor industry, integrated circuits and micro-electronic items immediately resume the original advantages which it has established as a good foundation. These years, according to MS, we can see that the market share of Korean integrated circuits and micro-electronic components products in international is relatively stable at 7-8 per cent (see table 2 ).

From the RCA and TC index we can see that Chinese integrated circuits and micro-electronic components has been comparative disadvantage products, but as seen from the numerical change, the competitiveness of the products has been increasing, additionally, Market share are also constantly improved (see table 3 ).

2.3 The competitiveness comparison of Chinese integrated circuit and micro-electronic components product with the products of the United States and South Korea

The United States is a "model country" of China, which is the direction of the future development of integrated circuits and micro-electronic components product. Considerable gap of the competitiveness of Chinese integrated circuits and micro-electronic components still exist.

South Korea is the "sample country" of China, which is the example of countries we can follow to improve and learn. Similarly, the competitiveness of Chinese products is far below South Korea; however, the difference is that the various indicators of China are improvement while the indicators of South Korea are in a balanced or weakened. Obviously, the competitiveness power of Chinese integrated circuits and micro-electronic components of the product is lower than South Korea.

\section{The analysis of the affect of FDI on the competitiveness of the integrated circuits and micro-electronic} components

\subsection{The establishment of the model}

Analysis model is established based on the impact of FDI on the exports of the integrated circuits and micro-electronic components: Export $=\mathrm{C}+\mathrm{a}$ FDI. According to the data of export and FDI from 1992 to 2006 (Date source: Statistical Yearbook of Chinese economy and the Korean National Statistical Office), the model is built and the results are obtained as follows with doing regression analysis (figures in brackets is the value of $\mathrm{t}$ statistics):

China: Export $=-6.59 * 10^{9}+0.05 * \mathrm{FDI}$

$$
(-5.4354) \quad(10.4175)
$$

$\mathrm{N}=15 \quad \mathrm{R}^{2}=0.8930 \quad \mathrm{~F}=108.5255$

South Korea: Export $=1.09 * 10^{10}+0.11 * \mathrm{FDI}$

$$
\text { (6.6734) (3.7720) }
$$

$\mathrm{N}=15 \quad \mathrm{R}^{2}=0.8225 \quad \mathrm{~F}=14.2284$

\subsection{Economic significance}

(1) Each dollar of FDI put into China will enhance 5 percent of the export of integrated circuits and micro-electronic components; each dollar of FDI in South Korea will enhance 11 percent of the exports of the integrated circuits and micro-electronic components.

(2) Through the Analysis of the two results, we can see that there is still great space for improvement for the use of FDI in China with the comparison of South Korea, or we can say that the more FDI put into china, the better development the integrated circuits and micro-electronic components products will get.

4. The improvement space of the utilization of FDI on the competitiveness of integrated circuits and micro-electronic components in China

As we can see, each dollar of FDI put into South Korea will enhance 11 percent of the exports of the integrated circuits and micro-electronic components; however, this number in china is just 5, which indicate that there is still a lot of improvement space of the utilization of FDI on the competitiveness of integrated circuits and micro-electronic components. In this aspect, South Korea is a country we can learn. 
In 1980s, the "large-scale integrated circuit project", used the cooperation between laboratories run by private sector and institute of public sector to make South Korea's chip makers playing the main role in the world's electronics manufacturing industry.

After the financial crisis in 1997, South Korea implemented "the plan of three-year economic recovery", established a strategic on high-tech industries, further adjusted to foreign investment policy. Then South Korea became the power country which can attract more FDI than other country, what's more, it also strengthen the competitiveness of FDI on the effectiveness of products.

The South Korean government focuses on the technical development after 2010 and has drawn up a "new areas of research in 21 st century projects". Including the choice of integrated circuits and micro-electronic components, South Korea has selected many of its advantages trip to do research.

In 2000, China promulgated "the policy on encouraging the development of the software industry and integrated circuit industries" (the State Council (2000), the 18th). This creates a favorable policy environment for the development of integrated circuit industry, which has greatly aroused the enthusiasm of all sectors of the community to develop integration Circuit industries. This is two years later than South Korea in terms of policy; therefore China should pay more attention to the effects of the issue when introduce FDI.

In my opinion, I think we should primarily focus on the following two aspects:

(1) China, as a developing country, should pay more attention on the indirect effects of FDI contributing to technological progress, upgrading the industrial structure and improving product competitiveness. Through the use of foreign capital, it can integrate ownership advantages and the host country's comparative advantage organically, prompt foreign investors to strengthen the key link of product in the value chain of investment, and it also can increase exports of products value-added and technology, as well as using multinational companies production and marketing system in the world; what's more, it can continuously improve Chinese participation in the international division of labor, and enhance Chinese international division status.

(2) We need to actively cultivate the true sense of the competitive market structure in foreign investment industrial fields, in order to make foreign-funded enterprises and domestically-funded enterprises within the same "national treatment" conditions to participate in competition, support domestically-funded enterprises which have ability to compete to compete with foreign-funded enterprises. At the same time, in the foreign-found monopoly field, we also should introduce competitive foreign competitors. Through increasing intensity of the competition between domestic and foreign-funded enterprises, it can force foreign-funded enterprises to transfer advanced production technology and Management technology under the pressure of high-level competition. Driven by the motive of lower costs also can speed up the process of localization of production factors. And domestic enterprises can also enjoy more from the technology spillover effects, which can really promote the competitiveness of Chinese products upgrading.

\section{References}

F. Gerard Adams, Byron Gangnes and Yochanan Shachmurove, Why is China so Competitive? Measuring and Explaining China's Competitiveness. World Economy. Feb.2006 pp. 96-120.

http://comtrade.un.org (May, 2008)

Kyoo-HoPark and Keun Lee, Linking the Technological Regime to the Technological Catch-up: Analyzing Korea and China's Taiwan Region Using the US Patent Data, Proceedings of The 2nd Globelics Conference, Beijing: Tsingh University Press, 2004.

Michael Porter. National competitive Advantages. Beijing: Huaxia Press, 2002.

Stefano Bresch,i Franco Malerba and Luigi Orsenigo, Techlogical Regimes and Schumpeterian Patterns of Innovation The Economic Journal, 2000.

Tan, Liwen, Chen Limin, The Empirical Method of International Competitiveness of Chinese Manufacturing Sector---and The Comparison with indicators and Industry Classification of Porte. Chinese industrial economy, 2004.5 pp. 30-37.

Zhang, Huasheng, Xue Lan. The comparative analysis of Chinese knowledge of the manufacturing sector, scale, cost-effective and industrial economy, Chinese industrial economy, 2003.2 pp. 15-22. 
Table 1. Three indexes of U.S. integrated circuits and micro-electronic components

\begin{tabular}{|c|c|c|c|}
\hline \multicolumn{4}{|c|}{$\begin{array}{l}\text { Three indexes of U.S. integrated circuits and micro-electronic } \\
\text { components }\end{array}$} \\
\hline & RCA & $\mathrm{TC}$ & MS \\
\hline 2006 & 1.4668 & 0.0220 & 0.1330 \\
\hline 2005 & 1.5628 & 0.0216 & 0.1401 \\
\hline 2004 & 1.6411 & 0.0237 & 0.1509 \\
\hline 2003 & 1.7891 & 0.0275 & 0.1762 \\
\hline 2002 & 1.6758 & 0.0214 & 0.1851 \\
\hline 2001 & 1.7028 & 0.0182 & 0.2079 \\
\hline 2000 & 1.7081 & 0.0138 & 0.2145 \\
\hline 1999 & 1.7378 & 0.0126 & 0.2201 \\
\hline 1998 & 1.6332 & 0.0060 & 0.2109 \\
\hline 1997 & 1.6808 & 0.0031 & 0.2179 \\
\hline 1996 & 1.8251 & -0.0015 & 0.2275 \\
\hline 1995 & 1.8123 & -0.0078 & 0.2256 \\
\hline 1994 & 1.7762 & -0.0012 & 0.2421 \\
\hline 1993 & 1.6257 & -0.0008 & 0.2668 \\
\hline 1992 & 1.6548 & 0.0012 & 0.3012 \\
\hline
\end{tabular}

Table 2. Three indexes of South Korean integrated circuits and micro-electronic components

\begin{tabular}{|c|c|c|c|}
\hline \multicolumn{1}{|l}{$\begin{array}{l}\text { Three indexes of South Korean integrated circuits and } \\
\text { micro-electronic components }\end{array}$} & TC \\
\hline & RCA & 0.0789 & 0.0736 \\
\hline 2006 & 2.5869 & 0.0718 & 0.0813 \\
\hline 2005 & 2.8845 & 0.0063 & 0.0722 \\
\hline 2004 & 2.5299 & -0.0902 & 0.0650 \\
\hline 2003 & 2.4642 & -0.1049 & 0.0594 \\
\hline 2002 & 2.2942 & -0.0918 & 0.0578 \\
\hline 2001 & 2.3003 & 0.0823 & 0.0793 \\
\hline 2000 & 2.8613 & 0.1304 & 0.0919 \\
\hline 1999 & 3.4977 & 0.2099 & 0.0999 \\
\hline 1998 & 3.9781 & 0.1904 & 0.0989 \\
\hline 1997 & 3.8525 & 0.2392 & 0.0988 \\
\hline 1996 & 3.8065 & 0.3893 & 0.1204 \\
\hline 1995 & 4.5093 & 0.3173 & 0.1040 \\
\hline 1994 & 4.0699 & 0.2164 & 0.0991 \\
\hline 1993 & 3.4114 & 0.1419 & 0.1293 \\
\hline 1992 & 4.1470 & & \\
\hline & & & MS \\
\hline
\end{tabular}


Table 3. Three indexes of Chinese integrated circuits and micro-electronic components

\begin{tabular}{|l|c|c|c|}
\hline \multicolumn{4}{|l}{$\begin{array}{l}\text { Three indexes of Chinese integrated } \\
\text { micro-electronic components }\end{array}$} \\
\hline & RCA & TC & MS \\
\hline 2006 & 0.7312 & -0.6651 & 0.0619 \\
\hline 2005 & 0.6455 & -0.6983 & 0.0488 \\
\hline 2004 & 0.5917 & -0.6922 & 0.0395 \\
\hline 2003 & 0.4641 & -0.7279 & 0.0277 \\
\hline 2002 & 0.4028 & -0.7188 & 0.0209 \\
\hline 2001 & 0.3039 & -0.7323 & 0.0135 \\
\hline 2000 & 0.2905 & -0.6489 & 0.0116 \\
\hline 1999 & 0.2966 & -0.5876 & 0.0106 \\
\hline 1998 & 0.2039 & -0.6183 & 0.0071 \\
\hline 1997 & 0.1657 & -0.5925 & 0.0057 \\
\hline 1996 & 0.1365 & -0.6418 & 0.0041 \\
\hline 1995 & 0.0979 & -0.6901 & 0.0031 \\
\hline 1994 & 0.0511 & -0.8238 & 0.0016 \\
\hline 1993 & 0.0354 & -0.8791 & 0.0011 \\
\hline 1992 & 0.0440 & -0.8424 & 0.0015 \\
\hline & & &
\end{tabular}

